\title{
Tungsten oxide modified AITUD-1 mesoporous acid catalyst for synthesis of thiazole aryl imines and phenylhydrazones
}

\author{
M. Rajarajan ${ }^{1}$ - M. P. Pachamuthu ${ }^{2}$ (D) G. Thirunarayanan ${ }^{3} \cdot$ G. Vanangamudi ${ }^{4} \cdot$ Mohamed S. Hamdy $^{5}$
}

(c) Springer Nature Switzerland AG 2019

\begin{abstract}
A non-surfactant route synthesized mesoporous AITUD-1 (Si/Al=25) with interconnected porous networks effectively utilized as a support for $10 \mathrm{wt} \%$ tungsten oxide $\left(\mathrm{WO}_{3}\right)$ dispersions. The synthesized $\mathrm{WO}_{3} / \mathrm{AITUD}-1$ catalyst was characterized by different techniques. $\mathrm{N}_{2}$ sorption and XRD studies were confirmed its amorphous mesoporous nature, which measured a pore diameter of $6.4 \mathrm{~nm}$ and a surface area of $510 \mathrm{~m}^{2} \mathrm{~g}^{-1}$. Presence of $\mathrm{WO}_{3}$ on the pores and silica TUD-1 wormhole structure were evaluated by techniques including DRUV Visible and FT-Raman. The catalyst possessed both Lewis (L) and Brønsted (B) acidity, as measured by pyridine adsorbed FT-IR, which is responsible for the catalyst activity. $\mathrm{WO}_{3} /$ AITUD-1 acid catalyst showed an excellent catalytic performance yield of about $80 \%$ at $80{ }^{\circ} \mathrm{C}$ in reflux condition, for different 1-substituted benzylidene 4-methylbenzo[d]thizole-2-amines (thiazole based aryl imines) and substituted phenylhydrazone compounds.
\end{abstract}

Electronic supplementary material The online version of this article (https://doi.org/10.1007/s42452-019-0928-z) contains supplementary material, which is available to authorized users.

$\triangle$ M.P. Pachamuthu, pachachem@gmail.com; pachamuthu@bitsathy.ac.in | ${ }^{1}$ Department of Chemistry, Thiruvalluvar Arts and Science College, Kurinjipadi, Tamil Nadu 607302, India. ${ }^{2}$ Department of Chemistry, Bannari Amman Institute of Technology, Sathyamangalam, Erode 638401, India. ${ }^{3}$ Department of Chemistry, Annamalai University, Annamalainagar 608002 , India. ${ }^{4}$ PG \& Research Department of Chemistry, Government Arts College, C-Mutlur, Chidambaram, 608102 , India. ${ }^{5}$ Chemistry Department, College of Science, King Khalid University, P.O. Box 9004, Abha 61413, Saudi Arabia. 


\section{Graphic abstract}

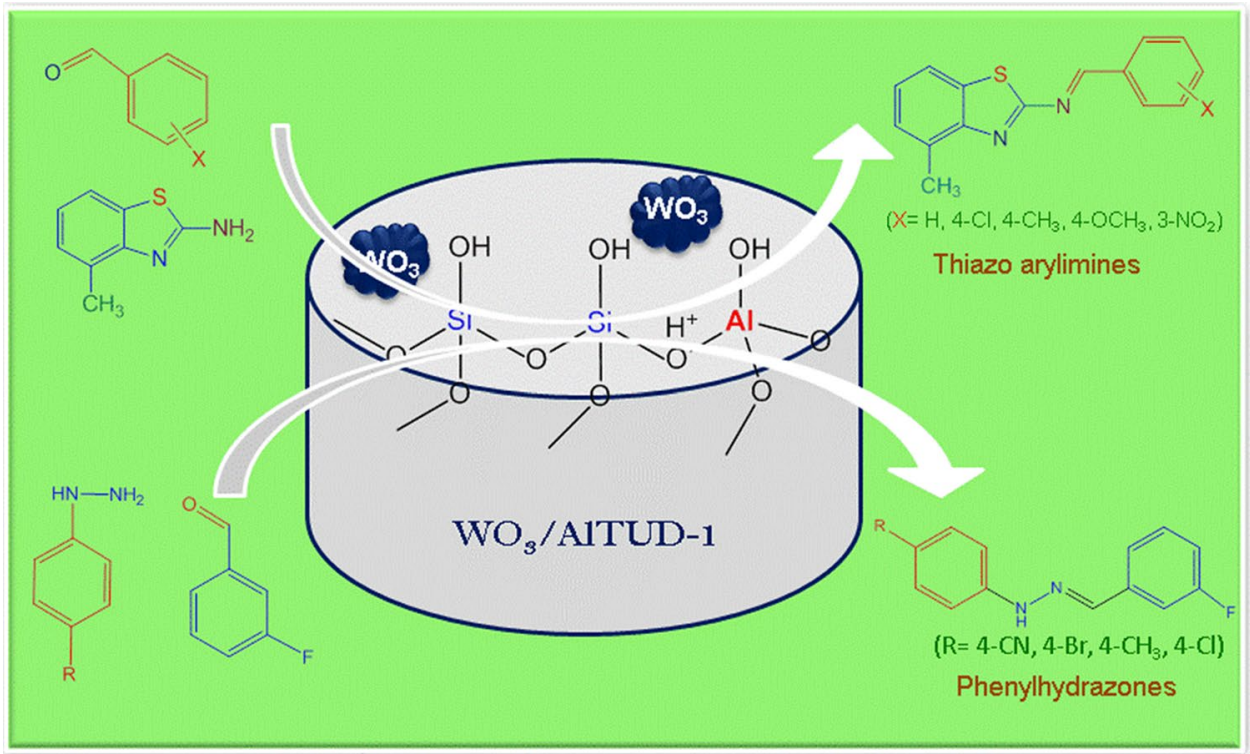

Keywords Mesoporous · Catalyst · Solid acid · AITUD-1 · Schiff bases

\section{Introduction}

Hydrazones and Schiff bases are versatile class of organic compounds. It contains azomethines $\left(\mathrm{R}-\mathrm{CH}=\mathrm{NR} \mathrm{R}^{\prime}\right)$ functionality, which is the common facture for both hydrazone and Schiff bases. These azomethine derivatives are interesting compounds because of their remarkable array of biological activity $[1,2]$. The literature reviews have shown that Schiff's base possess a broad range of physiological activities such as anti-microbial, antidyslipidemic, anthelmintic, anti-tuberculosis, anti-inflammatory, anti-convulsant, antitumor, antioxidant, anti-viral, antihypertensive and anti-diabetic activities [3]. Vicini et al. [4] have synthesized Benzo[d]isothiazole derivatives by the reaction of benzo[d]isothiazol-3-ylamine with substituted benzaldehydes in anhydrous benzene and the synthesized compounds were studied for biological evaluation. Meanwhile, owing to the unique $\mathrm{R}, \mathrm{R}^{\prime}-\mathrm{C}=\mathrm{N}-\mathrm{N}-\mathrm{R}^{\prime \prime}-\mathrm{R}^{\prime \prime \prime}$, structure (hydrazone) show a variety of antimicrobial activities, such as herbicide [5], anticonvulsant [6], antimicrobial [7], miticidal [8], antioxidant [9], and anticancer activities [10]. Recently, Rajarajan et al. [11] have synthesized phenylhydrazone derivatives and studied its antimicrobial activities.

Many green acid catalysts like $\mathrm{BiCl}_{3}-\mathrm{K} 10$ [12], $\mathrm{MgSO}_{4}-\mathrm{PPTL}$ [13], $\mathrm{SiO}_{2}-\mathrm{NaHSO}_{4}$ [14], PSSA [15], $\mathrm{K}-10$ montmorillonite [16], Tandam catalyst [17], $\mathrm{MgSO}_{4}-\mathrm{PPTS}$ [18], $\mathrm{Ti}(\mathrm{OR})_{4}$ [19] and $\mathrm{P}_{2} \mathrm{O}_{5}-\mathrm{SiO}_{2}$ [20] have been utilized for Schiff base and hydrazone compounds synthesis. However, there is a noticeable development required in catalyst structures. Typically, in the heterogeneous catalysts based organic transformation reactions, catalysts are revealing its good acidity, high surface area, stable and recyclability. Besides, various metal ions $\left(\mathrm{M}^{\mathrm{x}+}\right)$ and metal oxides $\left(\mathrm{M}_{\mathrm{x}} \mathrm{O}_{\mathrm{y}}\right)$ modified mesoporous materials (MCM-41, SBA-15, KIT-6, and TUD-1) have also been employed as a solid acid catalyst for many industrial important organic conversions. Notably, isolated tungsten (W) or oxides of tungsten-based mesoporous catalyst have received much attention, due to its acidity and redox properties [21-24]. Kundu et al. [25] reported that the effective utilization of tungstic acid modified SBA-15 acid catalyst for onepot condensation reaction of three components. Recently, W-TUD-1 [26] and WO $_{4} /$ TiTUD-1 [27] type mesoporous catalysts were tested as a solid acid catalyst for industrially relevant Prins cyclisation and esterification reactions. Hence, we have taken efforts for the synthesis of new $\mathrm{WO}_{3}$ modified AITUD- 1 catalyst and examined its activity for thiazole based aryl imines (1-substituted benzylidene 4-methylbenzo[d] thizole-2-amines) and substituted phenylhydrazone compounds preparation. These synthesized catalyst and products are characterized by different spectral techniques.

\section{Experimental}

\subsection{Catalyst synthesis}

AITUD-1 with Si/Al molar ratio of 25 was synthesized by sol-gel, hydrothermal method based on our previously reported procedure [28]. In a typical catalyst preparation, 
$21 \mathrm{~g}$ of tetraethyl orthosilicate (TEOS, Sigma Aldrich) and aluminium isopropoxide (Al (isop) ${ }_{3}$, Sigma Aldrich) were stirred for $10 \mathrm{~min}$. A mixture of $14 \mathrm{~g}$ of triethanolamine (TEA, SRL) and $5 \mathrm{~g}$ of water was then added to the above mixture and stirred vigorously for $1 \mathrm{~h}$. Finally, $19.8 \mathrm{~g}$ of tetraethylammonium hydroxide $(\mathrm{TEAOH}, 35 \%$, Sigma Aldrich) was slowly added to the prior solution under continuous stirring for another $2 \mathrm{~h}$. The above-obtained gel was aged at $30^{\circ} \mathrm{C}$ for $24 \mathrm{~h}$ and then dried at $100{ }^{\circ} \mathrm{C}$ for $24 \mathrm{~h}$. The final solid was kept for hydrothermal treatment at $\left(180^{\circ} \mathrm{C}\right)$ for $8 \mathrm{~h}$ and successively calcined at $600^{\circ} \mathrm{C}$ for $10 \mathrm{~h}$ to eliminate the organic molecules and water. 10 wt $\%$ of tungsten oxide supported on the amorphous AITUD- 1 catalyst (preheated $250{ }^{\circ} \mathrm{C}$ for $2 \mathrm{~h}$ ) is prepared by the conventional impregnation method using tungstic acid (Aldrich) solution. The mixture was stirred for $12 \mathrm{~h}$ and then dried at $100^{\circ} \mathrm{C}$ for $6 \mathrm{~h}$. Finally, the sample was calcined at $550^{\circ} \mathrm{C}$ for $6 \mathrm{~h}$ in an air atmosphere. The obtained material was mentioned as $\mathrm{WO}_{3}$ /AITUD- 1 .

\subsection{Catalyst characterizations}

Powder XRD patterns were obtained high angle region employed Rigaku diffractometer using $\mathrm{Cu} \mathrm{Ka}$ ray $(\lambda=1.5418 \AA$ A). FT-IR spectrum is measured on a Bruker spectrometer (Tensor) in DRIFT resolution of $4 \mathrm{~cm}^{-1}$. BET the specific surface area and BJH pore size distribution were determined from nitrogen sorption using Quantachrome (QuadrasorbSI) porosimeter equipment (77 K) at liquid nitrogen temperature. The morphology was examined by scanning electron micrographs (SEM) imaging using ESEM Quanta 200 with a resolution of $10 \mathrm{kV}$. Transmission electron microscopy (TEM) was performed on a FEI Tecnai G2 fitted with a CCD camera. Diffuse reflectance ultraviolet-visible (DR UV-Vis) spectrum of the sample was recorded on a Thermoscientific spectrometer (Evolution 600 ) with a diffuse reflectance attachment, using $\mathrm{BaSO}_{4}$ as the reference. FT-Raman spectra of the samples were attained on a Bruker system 1000R using 1064 nm (Nd:YAG laser source) excitation source.

\subsection{Synthesis of 1-substituted benzylidene-4-methylbenzo[d]thizole-2-amine over $\mathrm{WO}_{3} /$ AITUD-1}

In a typical reaction, equimolar quantities of substituted benzaldehyde $(0.01 \mathrm{~mol})$, 4-methylbenzo[d] thiazol-2-amine $(0.01 \mathrm{~mol})$ and $20 \mathrm{~mL}$ of absolute ethanol with $0.1 \mathrm{~g}$ of $\mathrm{WO}_{3} /$ AITUD- 1 catalyst were added to $50 \mathrm{~mL}$ round bottom (RB) flask fitted with temperature controlled oil bath and magnetic stirrer (Scheme 1). This solution was refluxed for $4 \mathrm{~h}$ and the reaction progress is monitored by TLC. After completion, the reaction mixture was cooled and washed with water. The product was recrystallized by ethanol to obtain as pale yellow solid. The uniformity of the final products was monitored by ascending thin layer chromatography (TLC) on silica gel-G. All the solvents used were analytical reagent grade. FT-IR spectra of the products were recorded on a Shimadzu-FT-IR spectrometer (range $4000-400 \mathrm{~cm}^{-1}$ ) in $\mathrm{KBr}$ pellets. The UV Visible absorption spectra under investigation were recorded on Shimadzu-1650 in spectral grade methanol $\left(\lambda_{\max }\right.$ in $\left.\mathrm{cm}^{-1}\right)$. ${ }^{1} \mathrm{H}$ NMR and ${ }^{13} \mathrm{C} \mathrm{NMR}$ spectra for analytical purpose were recorded in $\mathrm{CDCl}_{3}$ on a Bruker instrument at $400 \mathrm{MHz}$.

The products characterizations are shown below:

(E)- $N$-benzylidene-4-methylbenzo[d] thiazol-2-amine (3a): $\mathrm{C}_{15} \mathrm{H}_{12} \mathrm{~N}_{2} \mathrm{~S}$; M.pt: $161-162{ }^{\circ} \mathrm{C}$; UV Vis: 345,$222 ;$ FTIR $\left(\mathrm{KBr}, \mathrm{U} / \mathrm{cm}^{-1}\right)$ : (Ar-CH) 3024, (Ali-CH) 2922, (C=N thiazole $)$ 1562, $(\mathrm{CH}=\mathrm{N})$ 1602, (C-S-C) 754; ${ }^{1} \mathrm{H}$ (NMR) $(400 \mathrm{MHz}$, $\left.\mathrm{CDCl}_{3}, \mathrm{TMS}\right): \delta 7.07-8.19(8 \mathrm{H}, \mathrm{m}, \mathrm{Ar}-\mathrm{H}), 2.60\left(3 \mathrm{H}, \mathrm{s}, \mathrm{CH}_{3}\right)$, $8.11(1 \mathrm{H}, \mathrm{s}, \mathrm{N}=\mathrm{CH}) ;{ }^{13} \mathrm{C} \mathrm{NMR}\left(400 \mathrm{MHz}, \mathrm{CDCl}_{3}\right): \delta 18.1$ $\left(\mathrm{CH}_{3}\right), 169.4\left(\mathrm{C}=\mathrm{N}_{\text {thiazole }}\right), 146.1(\mathrm{C}=\mathrm{N}), 145.6-118.9$ (aromatic carbons).

(E)- $\mathrm{N}$-(4-chlorobenzylidene)-4-methylbenzo[d]thiazol2-amine (3b): $\mathrm{C}_{15} \mathrm{H}_{11} \mathrm{~N}_{2} \mathrm{SCl}$. M.pt: $130-131{ }^{\circ} \mathrm{C}$; UV Vis: 323, 271; FTIR $\left(\mathrm{KBr}, \mathrm{v} / \mathrm{cm}^{-1}\right)$ : $(\mathrm{Ar}-\mathrm{CH}) 3065$, (Ali-CH) 2922, $\left(\mathrm{C}=\mathrm{N}_{\text {thiazole }}\right) 1551,(\mathrm{CH}=\mathrm{N}) 1613,(\mathrm{C}-\mathrm{S}-\mathrm{C}) 745 ;{ }^{1} \mathrm{H}$ NMR (400 MHz, CDCl $3, \mathrm{TMS}): \delta$ 7.06-7.65 (8H, m, Ar-H), $2.59\left(3 \mathrm{H}, \mathrm{s}, \mathrm{CH}_{3}\right), 7.88(1 \mathrm{H}, \mathrm{s}, \mathrm{N}=\mathrm{CH}) ;{ }^{13} \mathrm{C}$ NMR $(400 \mathrm{MHz}$,

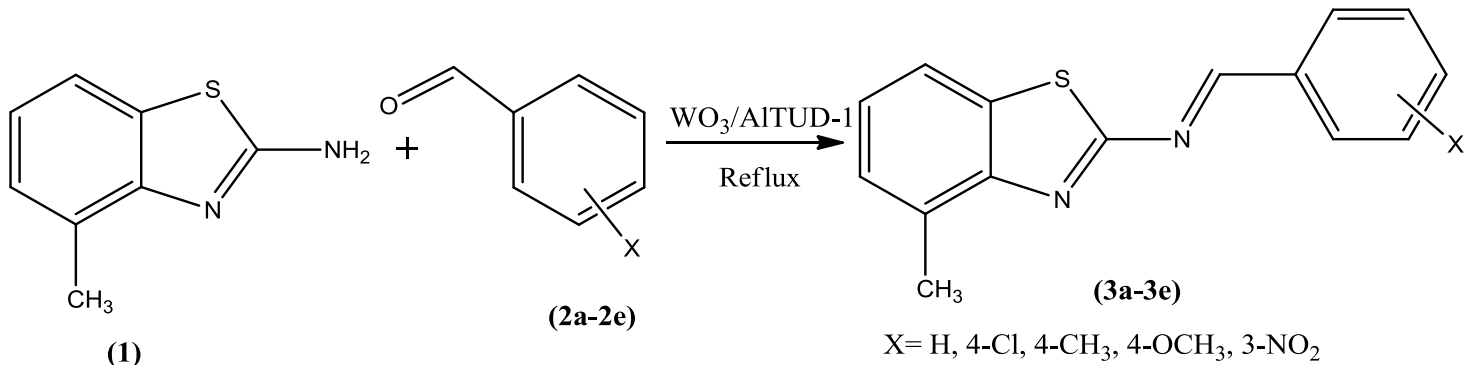

Scheme 1 Synthesis of aryl imines over $\mathrm{WO}_{3}$ /AITUD-1 catalyst 
$\left.\mathrm{CDCl}_{3}\right): \delta 18.03\left(\mathrm{CH}_{3}\right), 167.4\left(\mathrm{C}=\mathrm{N}_{\text {thiazole }}\right), 150.6(\mathrm{C}=\mathrm{N})$, 142.8-118.7 (aromatic carbons).

(E)-4-methyl- $\mathrm{N}$-(4-methylbenzylidene)benzo[d]thiazol2-amine (3c): $\mathrm{C}_{16} \mathrm{H}_{14} \mathrm{~N}_{2}$ S. M.pt.:107-108 ${ }^{\circ} \mathrm{C}$; UV Vis: 340 , 225; FTIR (KBr, v/cm $\left.{ }^{-1}\right)$ : (Ar-CH) 3064, (Ali-CH) 2922, $\left(\mathrm{C}=\mathrm{N}_{\text {thiazole }}\right) 1551,(\mathrm{CH}=\mathrm{N}) 1612,(\mathrm{C}-\mathrm{S}-\mathrm{C}) 744 ;{ }^{1} \mathrm{H}$ NMR (400 MHz, CDCl $\left.{ }_{3}, \mathrm{TMS}\right): \delta$ 7.06-7.65 (8H, m, Ar-H), 2.55 $\left(3 \mathrm{H}, \mathrm{s}, \mathrm{CH}_{3}\right), 2.39\left(3 \mathrm{H}, \mathrm{s}, \mathrm{CH}_{3}\right), 7.87(1 \mathrm{H}, \mathrm{s}, \mathrm{N}=\mathrm{CH}) ;{ }^{13} \mathrm{C} \mathrm{NMR}$ $\left(400 \mathrm{MHz}, \mathrm{CDCl}_{3}\right): \delta 18.1\left(\mathrm{CH}_{3}\right), 167.4\left(\mathrm{C}=\mathrm{N}_{\text {thiazole }}\right), 150.6$ $(\mathrm{C}=\mathrm{N}), 142.8-118.7$ (aromatic carbons).

(E)- $\mathrm{N}$-(4-methoxybenzylidene)-4-methylbenzo[d]thiazol-2-amine (3d): $\mathrm{C}_{16} \mathrm{H}_{14} \mathrm{~N}_{2} \mathrm{OS}$. M.pt.: $149-150{ }^{\circ} \mathrm{C}$; UV Vis: 338, 227; FTIR (KBr, U/cm $\left.{ }^{-1}\right)$ : (Ar-CH) 3061, (Ali-CH) 2924, $\left(\mathrm{C}=\mathrm{N}_{\text {thiazole }}\right) 1508,(\mathrm{CH}=\mathrm{N}) 1601,(\mathrm{C}-\mathrm{S}-\mathrm{C}) 741 ;{ }^{1} \mathrm{H}$ NMR (400 MHz, CDCl 3, TMS): $\delta 6.92-7.63(8 \mathrm{H}, \mathrm{m}, \mathrm{Ar}-\mathrm{H})$, $2.54\left(3 \mathrm{H}, \mathrm{s}, \mathrm{CH}_{3}\right), 3.85\left(3 \mathrm{H}, \mathrm{s}, \mathrm{OCH}_{3}\right), 7.83(1 \mathrm{H}, \mathrm{s}, \mathrm{N}=\mathrm{CH})$; ${ }^{13} \mathrm{C} \mathrm{NMR}(400 \mathrm{MHz}, \mathrm{CDCl}): \delta 18.1\left(\mathrm{CH}_{3}\right), 55.4\left(\mathrm{OCH}_{3}\right)$, $168.1\left(\mathrm{C}=\mathrm{N}_{\text {thiazole }}\right), 161.0(\mathrm{C}=\mathrm{N}), 148.6-114.2$ (aromatic carbons).

(E)-4-methyl- $N$-(3-nitrobenzylidene)benzo[d]thiazol2-amine (3e): $\mathrm{C}_{15} \mathrm{H}_{11} \mathrm{~N}_{3} \mathrm{O}_{2}$ S. M.pt.: $189-190{ }^{\circ} \mathrm{C}$; UV Vis: 340, 226; FTIR ( $\left.\mathrm{KBr}, \mathrm{v} / \mathrm{cm}^{-1}\right)$ : $(\mathrm{Ar}-\mathrm{CH})$ 3088, (Ali-CH) 2976, $\left(\mathrm{C}=\mathrm{N}_{\text {thiazole }}\right) 1533,(\mathrm{CH}=\mathrm{N}) 1599,(\mathrm{C}-\mathrm{S}-\mathrm{C}) 723 ;{ }^{1} \mathrm{H}$ $\operatorname{NMR}(400 \mathrm{MHz}, \mathrm{CDCl}, \mathrm{TMS}): \delta$ 7.07-8.22 $(8 \mathrm{H}, \mathrm{m}, \mathrm{Ar}-\mathrm{H})$, $2.52\left(3 \mathrm{H}, \mathrm{s}, \mathrm{CH}_{3}\right), 8.48(1 \mathrm{H}, \mathrm{s}, \mathrm{N}=\mathrm{CH}) i^{13} \mathrm{C} \mathrm{NMR}(400 \mathrm{MHz}$, $\left.\mathrm{CDCl}_{3}\right): \delta 17.9\left(\mathrm{CH}_{3}\right), 167.4\left(\mathrm{C}=\mathrm{N}_{\text {thiazole }}\right), 148.7(\mathrm{C}=\mathrm{N})$, 141.9-119.1 (aromatic carbons).

\subsection{Synthesis of hydrazones over $\mathrm{WO}_{3} /$ AITUD-1}

In a typical reaction, equimolar quantities of 3-fluoro benzaldehyde $(0.01 \mathrm{~mol})$, substituted phenylhydrazine $(0.01 \mathrm{~mol})$ and $20 \mathrm{~mL}$ of ethanol with $0.1 \mathrm{~g}$ of $\mathrm{WO}_{3} /$ AITUD-1 catalyst were added to $50 \mathrm{~mL}$ round bottom (RB) flask fitted with magnetic stirrer (Scheme 2). This solution was refluxed for $4 \mathrm{~h}$ and the reaction progress is monitored by TLC. After completion, the reaction mixture was cooled and washed with water. The product was recrystallized by ethanol to obtain as glittering solids. The uniformity of the final products was monitored by ascending TLC on silica gel-G.
The obtained products characterizations are shown below:

(E)-4-(2-(3-fluorobenzylidene)hydrazinyl) benzonitrile (6a): $\mathrm{C}_{14} \mathrm{H}_{10} \mathrm{FN}_{3}$; Mol.Wt. 239; M.pt.: $190-191^{\circ} \mathrm{C}$; UV Vis: 346, 288; FTIR (KBr, U/cm $\left.{ }^{-1}\right): 3045(\mathrm{Ar}-\mathrm{CH}), 3263(\mathrm{Ar}-\mathrm{NH})$, $1595(\mathrm{CH}=\mathrm{N}){ }^{1}{ }^{1} \mathrm{H}$ NMR $\left(400 \mathrm{MHz}, \mathrm{CDCl}_{3}, \delta, \mathrm{ppm}\right): 7.24-$ $7.92(\mathrm{~m}, 8 \mathrm{H}, \mathrm{Ar}-\mathrm{H}), 7.82(\mathrm{~S}, 1 \mathrm{H}, \mathrm{NH}) 7.98(\mathrm{~S}, 1 \mathrm{H},-\mathrm{N}=\mathrm{CH}-)$; ${ }^{13} \mathrm{C} \mathrm{NMR}\left(100 \mathrm{MHz}, \mathrm{CDCl}_{3}, \delta, \mathrm{ppm}\right): 148.3(\mathrm{CH}=\mathrm{N}), 144.5-$ 106.3 (aromatic carbons).

(E)-1-(4-bromophenyl)-2-(3-fluorobenzylidene) hydrazine (6b): $\mathrm{C}_{13} \mathrm{H}_{10} \mathrm{BrFN}_{2}$; Mol.Wt. 292; M.pt.: $100-101^{\circ} \mathrm{C}$; UV Vis: 338, 248; FTIR (KBr, U/cm $\left.{ }^{-1}\right)$ : $3078(\mathrm{Ar}-\mathrm{CH}), 3255$ $(\mathrm{Ar}-\mathrm{NH}), 1647(\mathrm{CH}=\mathrm{N}) ;{ }^{1} \mathrm{H}$ NMR $\left(400 \mathrm{MHz}, \mathrm{CDCl}_{3}, \delta\right.$, ppm): 7.14-7.85 (m, 8H, Ar-H), $7.86(\mathrm{~S}, 1 \mathrm{H}, \mathrm{NH}) 8.03(\mathrm{~S}$, $1 \mathrm{H},-\mathrm{N}=\mathrm{CH}-) ;{ }^{13} \mathrm{C}$ NMR $\left(100 \mathrm{MHz}, \mathrm{CDCl}_{3}, \delta, \mathrm{ppm}\right): 143.2$ $(\mathrm{CH}=\mathrm{N}), 137.1-112.1$ (aromatic carbons).

(E)-1-(3-fluorobenzylidene)-2-(4-tolyl) hydrazine (6c): $\mathrm{C}_{14} \mathrm{H}_{13} \mathrm{FN}_{2}$, Mol.Wt. 228; M.pt.: 122-123 ${ }^{\circ} \mathrm{C}$; UV Vis: 338, 248; FTIR (KBr, U/cm $\left.{ }^{-1}\right): 3055$ (Ar-CH), $3294(\mathrm{Ar}-\mathrm{NH})$, $1618(\mathrm{CH}=\mathrm{N}) ;{ }^{1} \mathrm{H}$ NMR $\left(400 \mathrm{MHz}, \mathrm{CDCl}_{3}, \delta, \mathrm{ppm}\right)$ : 7.57$7.10(\mathrm{~m}, 8 \mathrm{H}, \mathrm{Ar}-\mathrm{H}), 7.74(\mathrm{~S}, 1 \mathrm{H}, \mathrm{NH}) 7.91(\mathrm{~S}, 1 \mathrm{H},-\mathrm{N}=\mathrm{CH}-)$; $2.28\left(\mathrm{~S}, 3 \mathrm{H},-\mathrm{CH}_{3}\right) ;{ }^{13} \mathrm{C} \mathrm{NMR}\left(100 \mathrm{MHz}, \mathrm{CDCl}_{3}, \delta, \mathrm{ppm}\right)$ : $147.9(\mathrm{CH}=\mathrm{N}), 140.5-101.7$ (aromatic carbons), 28.7 $\left(\mathrm{CH}_{3}\right)$.

(E)-1-(4-chlorophenyl)-2-(3-fluorobenzylidene) hydrazine (6d): $\mathrm{C}_{13} \mathrm{H}_{10} \mathrm{ClFN}_{2}$, Mol.Wt. 248; M.pt.: $112-113^{\circ} \mathrm{C}$; UV Vis: 351, 310; FTIR (KBr, U/cm $\left.{ }^{-1}\right)$ : $3053(\mathrm{Ar}-\mathrm{CH}), 3315$ $(\mathrm{Ar}-\mathrm{NH}), 1591(\mathrm{CH}=\mathrm{N}) ;{ }^{1} \mathrm{H}$ NMR $\left(400 \mathrm{MHz}, \mathrm{CDCl}_{3}, \delta\right.$, ppm): 7.00-7.90 (m, 8H, Ar-H), $7.62(\mathrm{~S}, 1 \mathrm{H}, \mathrm{NH}) 7.92(\mathrm{~S}$, $1 \mathrm{H},-\mathrm{N}=\mathrm{CH}-) ;{ }^{13} \mathrm{C}$ NMR $\left(100 \mathrm{MHz}, \mathrm{CDCl}_{3}, \delta, \mathrm{ppm}\right): 142.3$ $(\mathrm{CH}=\mathrm{N}), 141.4-114.3$ (aromatic carbons).

\section{Results and discussion}

\subsection{Catalyst characterization}

The high angle $\left(2 \theta=5^{\circ}-80^{\circ}\right)$ XRD patterns of AITUD-1 and typical $\mathrm{WO}_{3}$ /AITUD-1 catalysts are depicted in Fig. 1 . AITUD- 1 and $\mathrm{WO}_{3} /$ AITUD- 1 exhibits a broad diffraction peak in the $2 \theta$ range of $10^{\circ}-30^{\circ}$, due to the presence of
Scheme 2 Synthesis of phenylhydrazones over $\mathrm{WO}_{3} /$ AITUD-1 catalyst
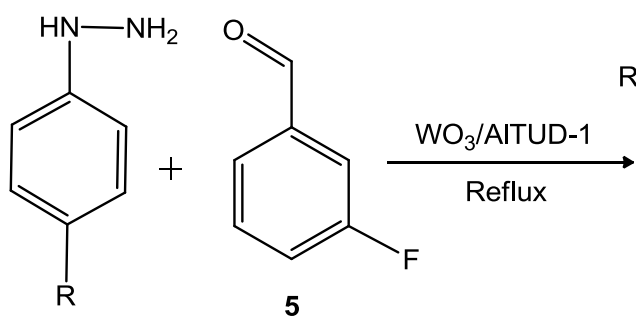<smiles>[R]c1ccc(N/N=C/c2cccc(F)c2)cc1</smiles>

(4a-4d) $\mathrm{R}=4-\mathrm{CN}, 4-\mathrm{Br}, 4-\mathrm{CH}_{3}, 4-\mathrm{Cl}$ 
amorphous silica $\left(\mathrm{SiO}_{2}\right)$. An absence of alumina peaks in XRD patterns of AITUD-1, confirmed the complete incorporation of $\mathrm{Al}^{3+}$ into TUD-1 framework $[28,29]$. Besides, the XRD patterns of the $\mathrm{WO}_{3}$ /AITUD- 1 catalyst displayed the minimal diffraction peaks at $23.6^{\circ}, 33.6^{\circ}$ and $54.5^{\circ}$ related to $\mathrm{WO}_{3}$ crystalline species $[23,26]$. This clearly indicated that the $\mathrm{WO}_{3}$ species are finely dispersed on internal porous walls and an external surface of TUD-1.

The $\mathrm{N}_{2}$ adsorption desorption isotherms and pore size distribution of typical $\mathrm{WO}_{3} / \mathrm{TUD}-1$ catalyst are represented in Fig. 2. According to the IUPAC classification, type IV isotherm with $\mathrm{H} 2$ hysteresis loop is exhibited, indicating the characteristic of TUD-1 type wormhole pore architectures $[23,26,29]$. The steep desorption and sloping adsorption clearly indicate that the presence of interconnected porous networks [26]. Moreover, the isotherm showed a sharp variation at a relative pressure between 0.6 and 0.9 representing the typical capillary condensation within pores. It is found that catalyst exhibited a surface area of $510 \mathrm{~m}^{2} \mathrm{~g}^{-1}$. The pore size distribution (Fig. $2 \mathrm{~b}$ ) measured from the desorption branch using the BJH model with a peak of around $6.4 \mathrm{~nm}$. Also, the pore size distribution of the catalyst had narrow pore size distribution and the sharpness indicated the uniformity of mesopore distribution.

The FT-IR spectra of $\mathrm{WO}_{3} /$ AITUD- 1 and AITUD- 1 catalyst are shown in Fig. 3. The catalysts exhibited the bands at $3450,1640,1223,1100$ and $803 \mathrm{~cm}^{-1}$. The bands at $3450 \mathrm{~cm}^{-1}$ and $1640 \mathrm{~cm}^{-1}$ are mainly caused by the $\mathrm{O}-\mathrm{H}$ stretching vibration and bending vibration mode of the adsorbed water molecules or surface silanol groups (Si-O-H). Further, the peaks observed at 1223, 1100 and $803 \mathrm{~cm}^{-1}$ are due (Si-O-Si) asymmetric and symmetric stretching vibrations. The similar type of vibration bands were reported for metal (Co, Sn, Ti, Zr) containing TUD-1

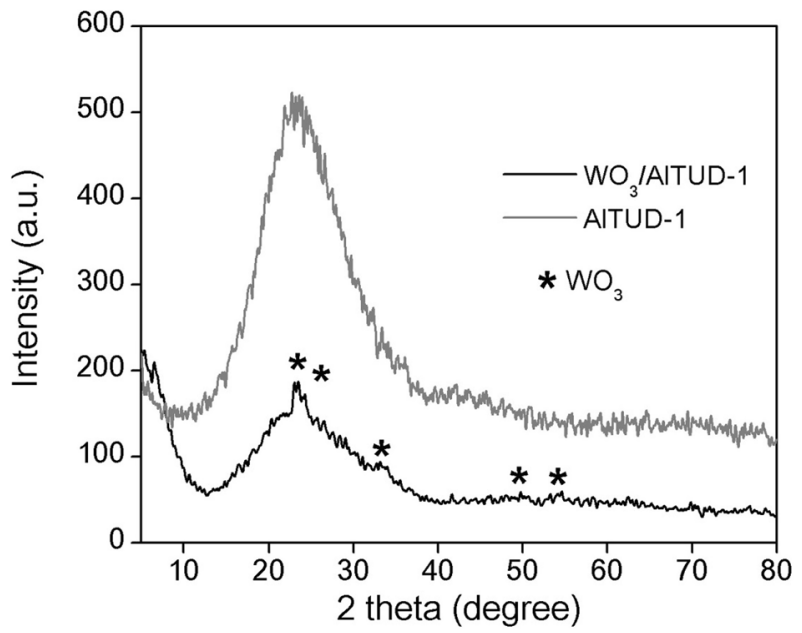

Fig. 1 Wide angle XRD of AITUD- 1 and WO$_{3} /$ AITUD-1
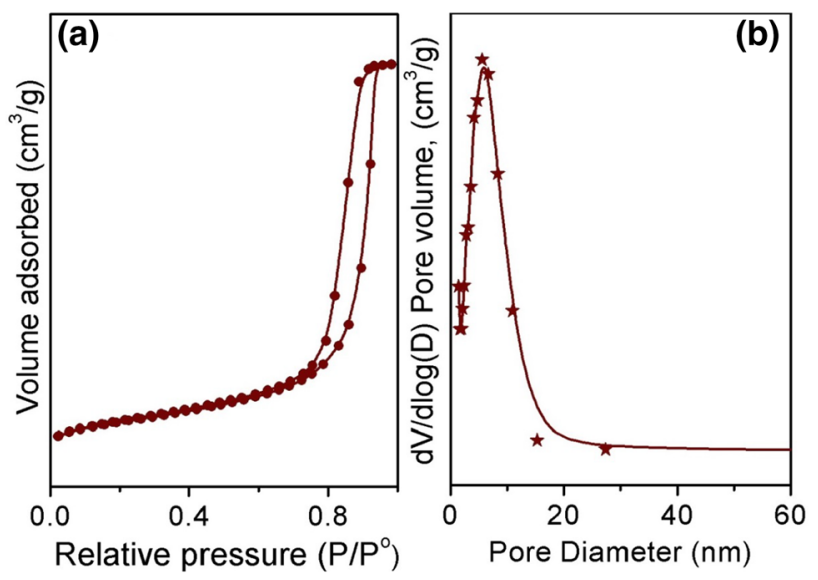

Fig. 2 a $\mathrm{N}_{2}$ adsorption-desorption isotherms and $\mathbf{b}$ BJH pore size distribution of $\mathrm{WO}_{3} /$ AITUD-1

silicates [29-32]. Noticeably, the vibration bands corresponding for $\mathrm{WO}_{3}$ in the $\mathrm{WO}_{3} /$ AITUD-1 catalyst are shielded by the bands of AITUD-1.

The FT-Raman spectra of $\mathrm{WO}_{3} /$ AITUD-1, AITUD-1, and $\mathrm{WO}_{3}$ are presented in Fig. 4. In comparison with $\mathrm{WO}_{3} /$ AITUD-1 and bulk $\mathrm{WO}_{3}$ four peaks were noticed at 807 , 718,326 and $273 \mathrm{~cm}^{-1}$ which confirms the presence of crystalline $\mathrm{WO}_{3}$ species [23]. These peaks are assigned to the deformation mode of $\mathrm{W}-\mathrm{O}-\mathrm{W}$, symmetric stretching mode of $\mathrm{W}-\mathrm{O}$ and bending mode of $\mathrm{W}-\mathrm{O}$, respectively $[26$, 27]. Apart from $\mathrm{WO}_{3}$ peaks, an intense band at $976 \mathrm{~cm}^{-1}$ was observed, which can be assigned to poly tungstate species or terminal bond $\mathrm{W}=\mathrm{O}$ of the tetrahedrally coordinated $\mathrm{WO}_{3}$ over the AITUD-1 surface [27, 33]. Bhuiyan et al. [34] had assigned $970 \mathrm{~cm}^{-1}$ peak as the terminal $\mathrm{W}=\mathrm{O}$ (symmetric stretching) mode of tungsten oxide

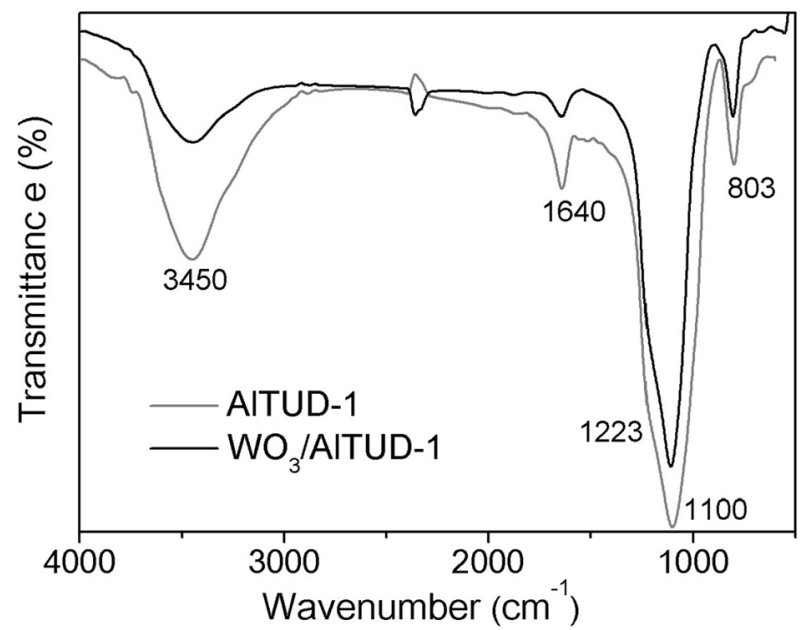

Fig. 3 FTIR spectra of AITUD-1 and WO$_{3} /$ AITUD-1 sample 


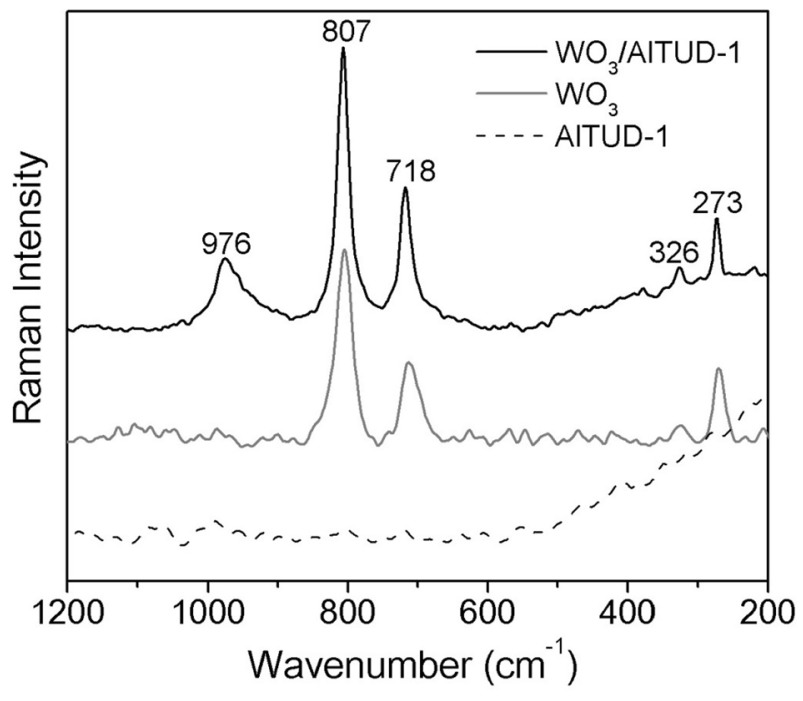

Fig. 4 FT-Raman spectra AITUD-1, $\mathrm{WO}_{3}$ /AITUD-1 and bulk $\mathrm{WO}_{3}$

(tetrahedrally coordinated) species, which are active sites for metathesis reactions.

SEM and TEM micrographs of $\mathrm{WO}_{3} /$ AITUD- 1 are shown in Fig. 5. From, the SEM image (Fig. 5a), the sample showed the disordered shapes with micrometer size of $\mathrm{SiO}_{2}$ particles with dispersed $\mathrm{WO}_{3}$ particles. The sponge- or wormhole-like three-dimensionally connected mesopore network which is typical for TUD-1 materials was further confirmed by TEM [31, 32] (Fig. 5b). Furthermore, due to low $\mathrm{WO}_{3}$ loading and contrast, it was difficult to identify the metal oxide phases in TEM image. The presence of Al, $\mathrm{W}$ and $\mathrm{Si}$ are confirmed by the ICP-OES and its quantities are similar to synthesis composition.

The UV-vis diffuse reflectance absorption spectrum of $\mathrm{WO}_{3}$ /AITUD-1 is displayed in Fig. 6 . A broad peak around $200-450 \mathrm{~nm}$ in the catalyst is due to the overlapping bands of isolated tetrahedral $\left[\mathrm{WO}_{4}\right]^{2-}$ species $(240 \mathrm{~nm})$, low oligomeric tungsten oxide species $\left(290 \mathrm{~nm}\right.$ ) and crystalline $\mathrm{WO}_{3}$ (380 and $450 \mathrm{~nm})[21,26,27]$. However, the absorbance

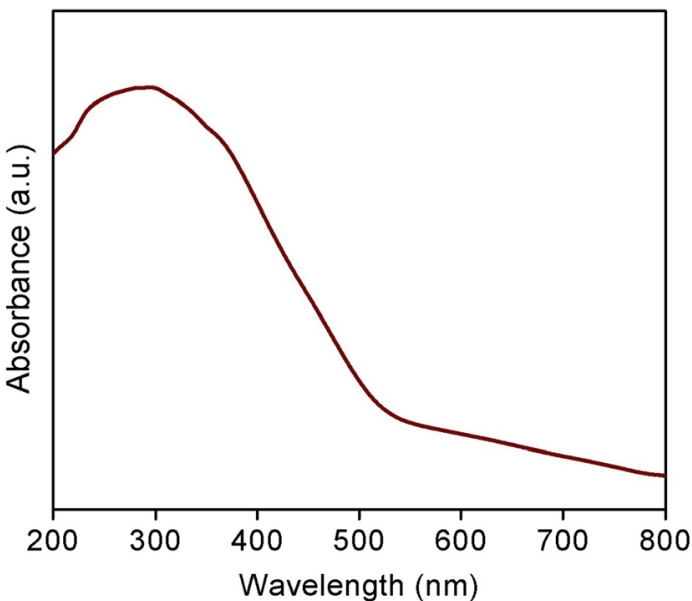

Fig. 6 DR UV Vis of $\mathrm{WO}_{3} /$ AITUD-1

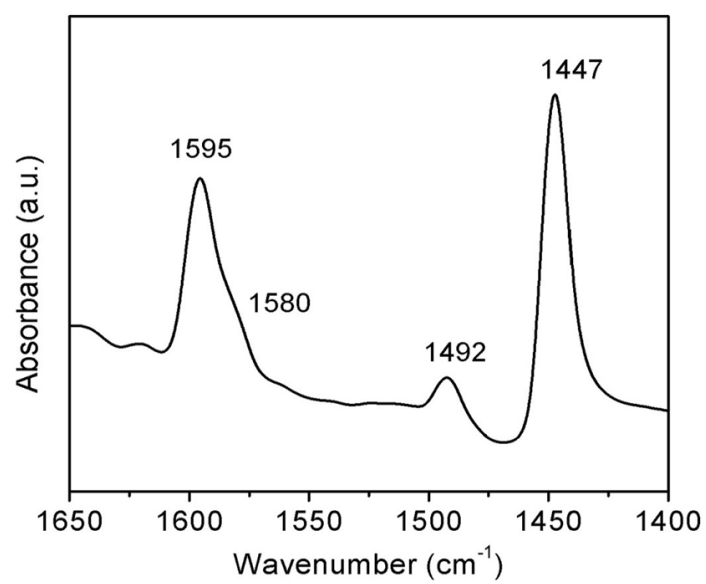

Fig. 7 FT-IR spectrum of pyridine adsorbed $\mathrm{WO}_{3}$ /AITUD-1

peak values are varied based on the $\mathrm{W}$ species (incorporated $\mathrm{W}$ or $\mathrm{WO}_{\mathrm{x}}$ ) and the architecture of mesoporous materials. The FT-IR spectrum of pyridine adsorbed on $W_{3} /$ AITUD- 1 catalyst in the region of $1650-1400 \mathrm{~cm}^{-1}$ is
Fig. 5 a SEM and b TEM images of $\mathrm{WO}_{3} /$ AITUD-1

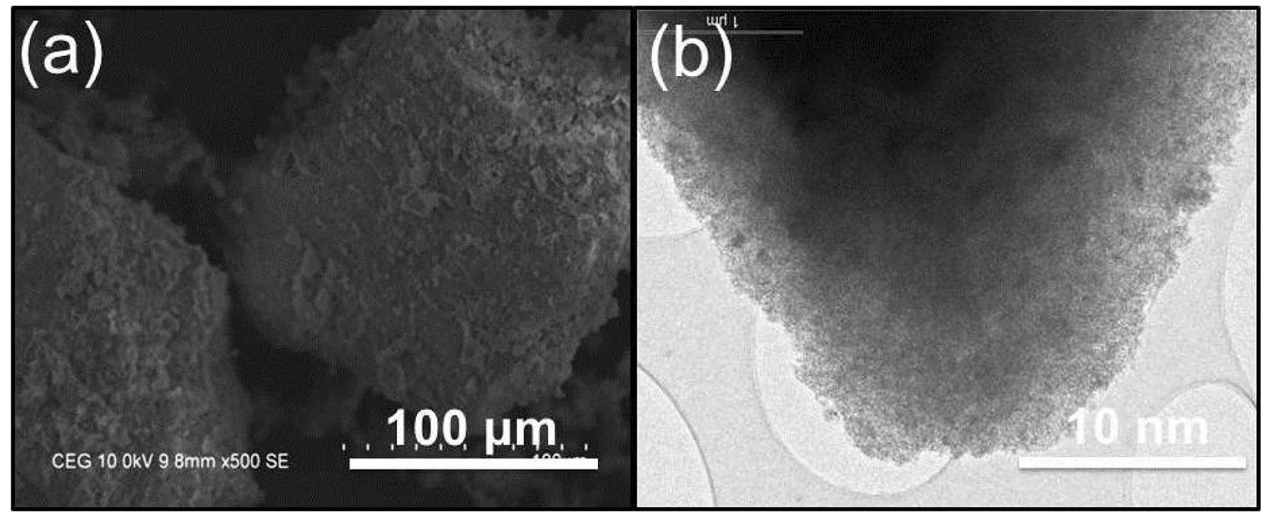

SN Applied Sciences

A SPRINGER NATURE journal 
depicted in Fig. 7. The bands at 1595 and $1447 \mathrm{~cm}^{-1}$ are due to the pyridine bonded to the Lewis acid sites [30, 32]. On the other hand, the band at $1492 \mathrm{~cm}^{-1}$ is due to the combinations of Lewis and Bronsted acid sites [26]. Besides, AITUD-1 leads to an increase in the Lewis acidity.

\subsection{Catalyst reactions}

The reaction conditions such as time, solvent, catalyst amount and temperature were optimized by screening as given in Schemes 1 and 2. Maximum yield was obtained at $80^{\circ} \mathrm{C}$ temperature, $20 \mathrm{~mL}$ of the solvent (ethanol), $0.1 \mathrm{~g}$ of catalyst and $4 \mathrm{~h}$ refluxing time. Further, we extended these optimized reaction conditions to differently substituted benzaldehydes with 4-methyl substituted benzo[d]thiazol2-amine and the obtained results are presented (Table 1). Notably, $83 \%$ of the maximum yield was obtained using the $\mathrm{WO}_{3} /$ AITUD- 1 as a catalyst. Substituted benzaldehyde with groups $-\mathrm{Cl},-\mathrm{NO}_{2},-\mathrm{OCH}_{3}$ and $-\mathrm{CH}_{3}$ (electron donating and withdrawing) groups in para position produce the corresponding products in good yields (70-80\%). Similarly, 3-fluro aldehyde reacts with different electron withdrawing and electron donating substituted hydrazine produces good yields (75-80\%) as shown in Table 2 . The yield of products clearly indicates the good dispersion of active $\mathrm{WO}_{3}$ and incorporated $\mathrm{Al}^{3+}$ species on the large porous
Table 1 Synthesis of different group substituted $(E)-N$ benzylidene-4-methylbenzo[d] thiazol-2-amines compounds

\begin{tabular}{ccc}
\hline No. & Aromatic aldehydes & Yield $^{\mathrm{a}}$ \\
$(\mathrm{X})$ & Product & $(\%)$ \\
\hline
\end{tabular}

1<smiles>O=Cc1ccccc1</smiles>

2<smiles>O=Cc1ccc(Cl)cc1</smiles>

3<smiles>Cc1ccc(C=O)cc1</smiles>

4<smiles>COc1ccc(C=O)cc1</smiles>

5

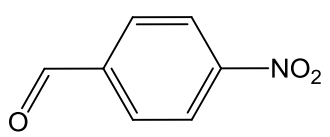<smiles>Cc1cccc2sc(/N=C/c3ccccc3)nc12</smiles>

Reaction conditions: Aromatic aldehydes $(0.01 \mathrm{~mol}), 4$-methylbenzo[d] thiazol-2-amine $(0.01 \mathrm{~mol})$, ethanol $(20 \mathrm{~mL})$, temperature $\left(80^{\circ} \mathrm{C}\right)$, catalyst $(0.1 \mathrm{~g})$ time $(4 \mathrm{~h})$

asolated yield 
Table 2 Synthesis of different phenylhydrazone compounds

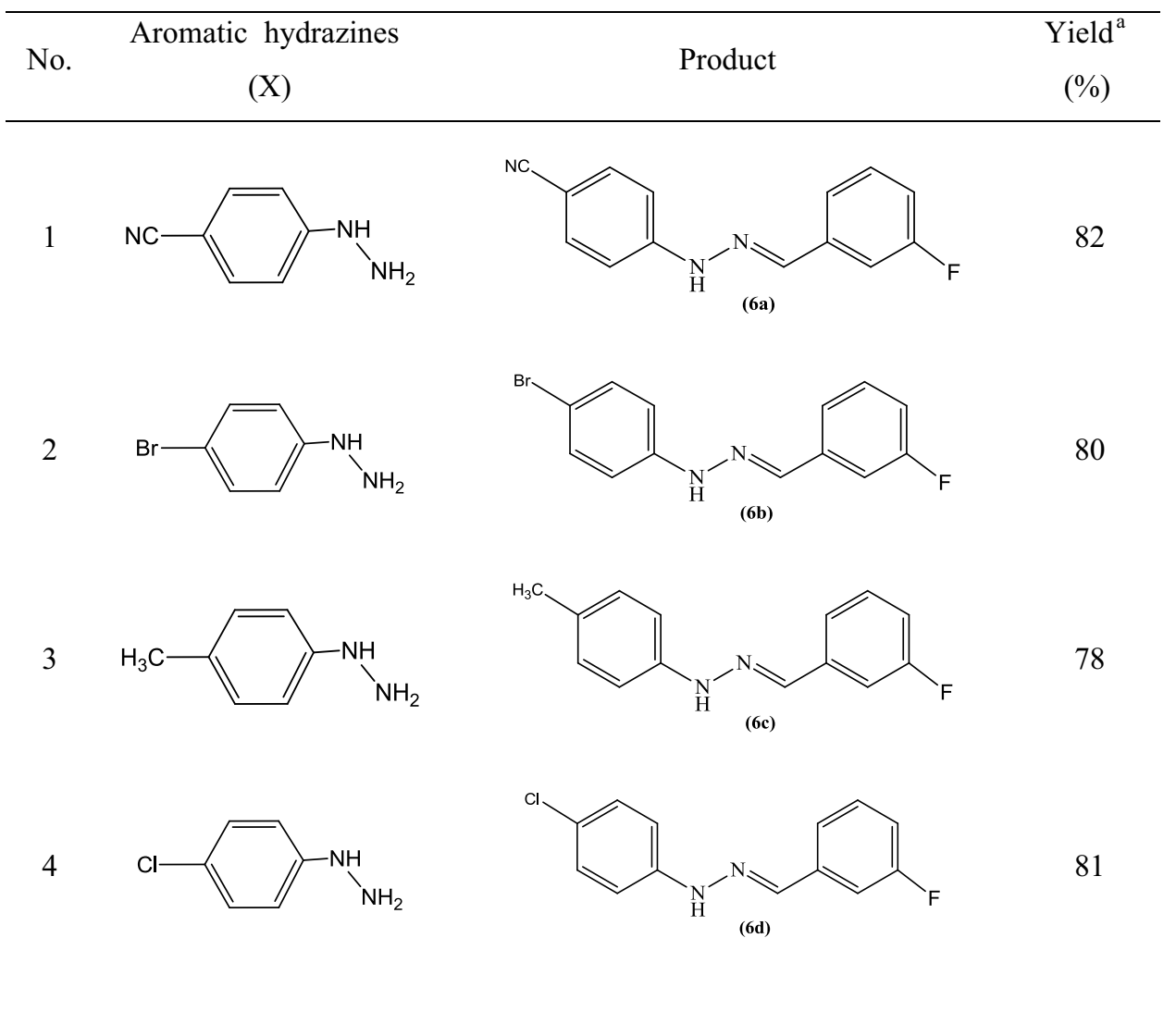

Reaction conditions: aldehyde $(0.01 \mathrm{~mol})$, substituted hydrazines $(0.01 \mathrm{~mol})$, ethanol $(20 \mathrm{~mL})$, temperature $\left(80^{\circ} \mathrm{C}\right)$, catalyst $(0.1 \mathrm{~g})$ time $(4 \mathrm{~h})$

asolated yield
TUD-1 support materials and interactions taking place between $\mathrm{WO}_{3}$ species and the AITUD-1 support [27].

The generally accepted mechanism of Schiff base reaction was proposed by many researchers [35, 36]. By following the mechanism reported by Kumar et al. [37] acid catalysed reaction mechanism is proposed in Scheme 3. The mechanism involves the protonation of both Schiff base and aldehyde with acidic $\mathrm{WO}_{3}$ /AITUD- 1 catalyst to option intermediate (1) and (2). This protonated Schiff base intermediate (1) attacked the carbonyl carbon of the intermediate (2) which gives intermediate (3) followed by proton transfer from nitrogen to oxygen to give an intermediate (4). This on further dehydration and deprotonation to produces imines. The solid acid catalyst ( $\mathrm{WO}_{3} /$ AITUD-1) promotes dehydration and deprotonation.

\section{Conclusions}

In summary, finely dispersed tungsten oxide $\left(\mathrm{WO}_{3}\right)$ introduced mesoporous AITUD-1 support was successfully synthesized by a modest synthesis procedure. The characterization studies confirmed amorphous, mesoporous and wormhole nature of the catalyst. This $\mathrm{WO}_{3} /$ AITUD-1 catalyst was presented as an efficient catalyst for synthesis of 1-substituted benzylidene-4-methylbenzo[d] thizole-2-amines (thiazo aryl imines) and phenylhydrazones $\sim 70-80 \%$ of the yield in the optimum reaction conditions. The solid acid catalyst $\left(\mathrm{WO}_{3} /\right.$ AITUD- 1$)$ promotes dehydration and deprotonation owing to the presence of acidic sites $(B+L)$. The catalytic activity related to framework incorporated $\mathrm{Al}^{3+}$, dispersed $\mathrm{WO}_{3}$ and the good 


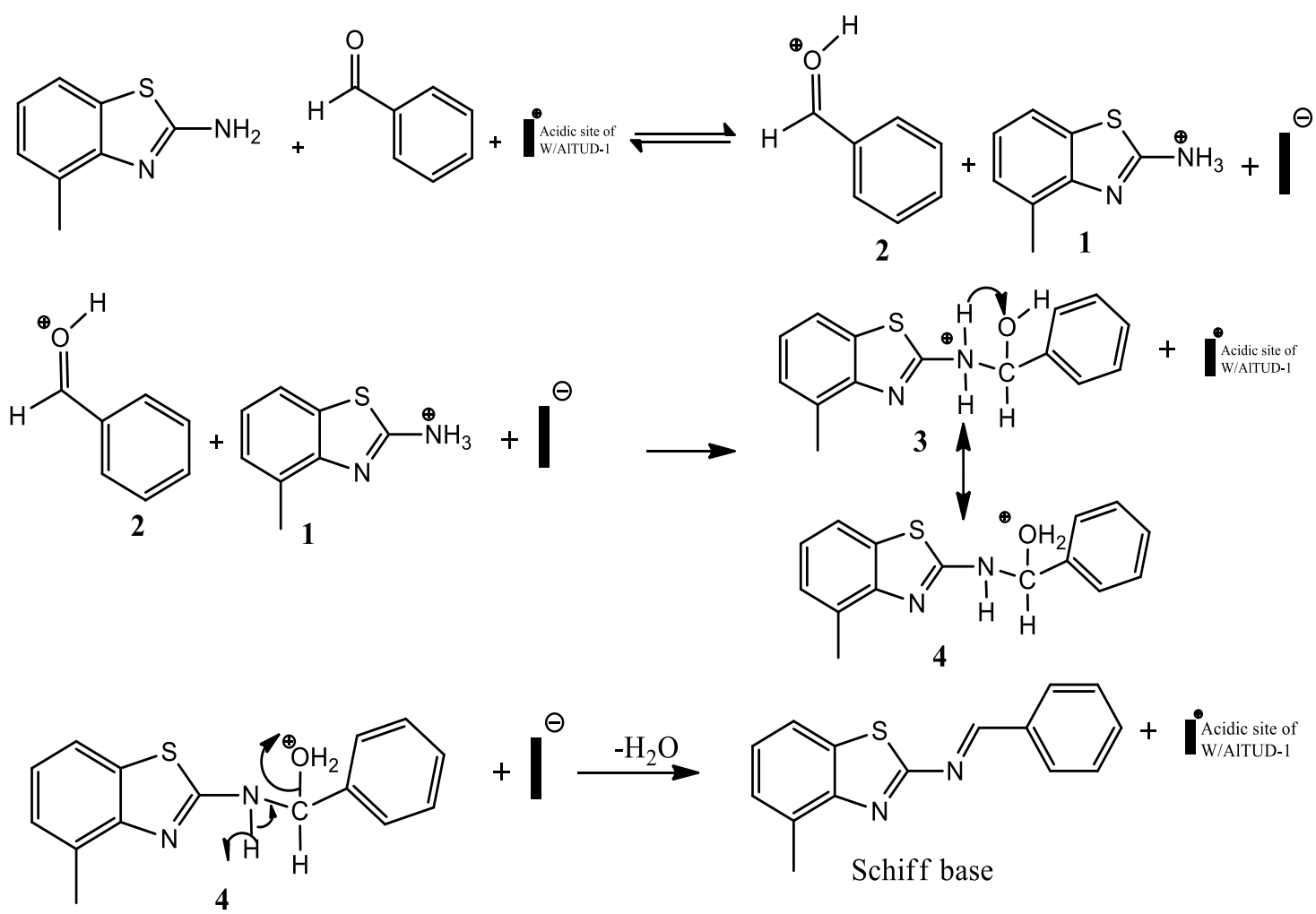

Scheme 3 The proposed mechanism for the formation Schiff base over $\mathrm{WO}_{3} /$ AITUD-1 catalyst

accessibility of these active sites to the reactants. Hence, we developed an efficient and simple alternative for the preparation of substituted benzo[d]thiazol-2-amines and phenylhydrazones via three-dimensional mesoporous acid catalyst under feasible reaction method. Further the studies will extend against other microbial species. Also, this catalyst can be exploited for the study of other heterogeneous acid catalysed organic transformations.

\section{Supplementary information (SI)}

The UV visible, FTIR and NMR $\left({ }^{1} \mathrm{H}\right.$ and $\left.{ }^{13} \mathrm{C}\right)$ spectral data of selective compounds are available in supplementary information (Figures S1-S12).

Acknowledgments The authors extend their appreciation to the Deanship of Scientific Research at King Khalid University for funding this work through General Research Project under Grant Number (R.G.P.1/45/39). The author MR thankful to the Department of Physics, Annamalai University, Annamalainagar-608002 for recording UV and IR spectral analysis. The author MPP thanks the Department of Chemistry, Anna University Chennai for the characterization supports.

\section{Compliance with ethical standards}

Conflict of interest The authors declare that they have no conflict of interest.

\section{References}

1. Lau KY, Mayr A, Cheung KK (1999) Synthesis of transition metal isocyanide complexes containing hydrogen bonding sites in peripheral locations. Inorg Chim Acta 285(2):223

2. Shawali AS, Harb NMS, Badahdah KO (1985) A study of tautomerism in diazonium coupling products of 4-hydroxycoumarin. J Heterocycl Chem 22(5):1397

3. Kajal A, Bala S, Kamboj S, Sharma N, Saini V (2013) Schiff bases: a versatile pharmacophore. J Catal 2013:1

4. Vicini $P$, Geronikaki A, Incerti M, Busonera B, Poni G, Cabrasc CA, Colla PL (2003) Synthesis and biological evaluation of benzo[d] isothiazole, benzothiazole and thiazole Schiff bases. Bioorg Med Chem 11:4785

5. Grossmann K, Caspar G, Kwiatkowski J, Bowe SJ (2002) On the mechanism of selectivity of the corn herbicide BAS $662 \mathrm{H}$ : a combination of the novel auxin transport inhibitor diflufenzopyr and the auxin herbicide dicamba. Pest Manag Sci 58:1002-1014

6. Dimmock JR, Vashishtha SC, Stables JP (2000) Anticonvulsant properties of various acetylhydrazones, oxamoylhydrazones and semicarbazones derived from aromatic and unsaturated carbonyl compounds. Eur J Med Chem 35:241-248 
7. Rajarajan M, Senbagam R, Vijayakumar R, Manikandan V, Balaji S, Vanangamudi G, Thirunarayanan G (2016) Synthesis, spectral correlations and antimicrobial activities of substituted 4-((E)2-benzylidenehydrazinyl)benzonitrile compounds. Indian J Chem 55B:197

8. Kaugars G, Gemrich EG, Rizzo VL (1973) Miticidal activity of benzoyl chloride phenylhydrazones. J Agric Food Chem 21:647-650

9. Belkheiri N, Bouguerne B, Bedos-Belval F, Duran H, Bemis C, Salvayre R, Negre-Salvayre A, Baltas M (2010) Synthesis and antioxidant activity evaluation of a syringic hydrazones family. Eur J Med Chem 45:3019-3026

10. Wiley RH, Clevenger RL (1962) Aldehyde hydrazone derivatives in cancer chemotherapy. J Med Pharm Chem 5:1367-1371

11. Rajarajan $M$, Senbagam R, Vijayakumar R, Manikandan V, Balaji S, Vanangamudi G, Thirunarayanan G (2016) Eco-friendly synthesis, spectral correlation analysis, and antimicrobial activities of substituted (E)-1-benzylidene-2-(3-nitrophenyl)hydrazines. Orbital: Electron J Chem 8(5):288-299

12. Ravi K, Krishnakumar B, Swaminathan M (2012) An efficient protocol for the green and solvent-free synthesis of azine derivatives at room temperature using $\mathrm{BiCl}_{3}$-loaded montmorillonite $\mathrm{K} 10$ as a new recyclable heterogeneous catalyst. ISRN Org Chem 2012:1

13. Branchaud BP (1983) Studies on the preparation and reactions of tritylsulfenimines. J Org Chem 48:3531

14. Bazgir A (2006) Microwave-assisted efficient synthesis of diimines in dry media using silica gel supported sodium hydrogen sulfate as reusable solid support. J Chem Res 37:1

15. Polshettiwar V, Varma RS (2008) Greener and expeditious synthesis of bioactive heterocycles using microwave irradiation. Pure Appl Chem 80(4):777

16. Abid M, Savolainen M, Landge S, Hu J, Suryaprakash GK, Olah GA, Torok B (2007) Synthesis of trifluoromethyl-imines bysolid acid/superacid catalyzed microwave assisted approach. J Fluor Chem 128:587

17. Barr DA, Donegn G, Grigg R (1989) Tandem Michael addition1,3-dipolar cycloaddition of imines of a-amino acid esters and aminoacetonitrile. J Chem Soc Perkin Trans 1:1550

18. Chakraborti AK, Bhagat S, Rudrawar S (2004) Magnesium perchlorate as an efficient catalyst for the synthesis of imines and phenylhydrazones. Tetrahedron Lett 45:7641

19. Dutheuil G, Bonnaire SC, Pannecoucke X (2007) Diastereomeric fluoroolefins as peptide bond mimics prepared by asymmetric reductive amination of a-fluoroenones. Angew Chem Int Ed Engl 46:1312

20. Devidas SM, Quadri SH, Kamble SA, Syed FM, Vyavhare DY (2011) Novel one-pot synthesis of schiff base compounds derived from different diamine \& aromatic aldehyde catalyzed by $\mathrm{P}_{2} \mathrm{O}_{5} / \mathrm{SiO}_{2}$ under free-solvent condition at room temperature. J Chem Pharm Res 3(2):489

21. Maheswari R, Pachamuthu MP, Ramanathan A, Subramaniam B (2014) Synthesis, characterization, and epoxidation activity of tungsten-incorporated SBA-16 (W-SBA-16). Ind Eng Chem Res 53:18833

22. Yan W, Ramanathan A, Ghanta M, Subramaniam B (2014) Towards highly selective ethylene epoxidation catalysts using hydrogen peroxide and tungsten or niobium-incorporated mesoporous silicate (KIT-6). Catal Sci Technol 4:4433

23. Zhang YQ, Wang SJ, Wang JW, Lou LL, Zhang C, Liu S (2009) Synthesis and characterization of Zr-SBA-15 supported tungsten oxide as a new mesoporous solid acid. Solid State Sci 11:1412

24. Bordoloi A, Halligudi SB (2010) Catalytic properties of $W_{x} / S B A-$ 15 for vapor-phase Beckmann rearrangement of cyclohexanone oxime. Appl Catal Gen 379A:141
25. Kundu SK, Mondal J, Bhaumik A (2013) Tungstic acid functionalized mesoporous SBA-15: a novel heterogeneous catalyst for facile one-pot synthesis of 2-amino-4H-chromenes in aqueous medium. Dalton Trans 42:10515

26. Ten Dam J, Badloe D, Ramanathan A, Djanashvili K, Kapteijn F, Hanefeld U (2013) Synthesis, characterisation and catalytic performance of a mesoporous tungsten silicate:W-TUD-1. Appl Catal Gen 468:150

27. Pachamuthu MP, Maheswari R, Ramanathan A (2017) Synthesis and characterizations of isolated $\mathrm{WO}_{4}$ anchored on Mesoporous TiTUD-1 support. Appl Surf Sci 402:286

28. Anand R, Maheswari R, Hanefeld U (2006) Catalytic properties of the novel mesoporous aluminosilicate AITUD-1. J Catal 242:82

29. Pasupathi M, Santhi N, Pachamuthu MP, Alamelu Mangai G, Ragupathi C (2018) Aluminium and titanium modified mesoporous TUD-1: a bimetal acid catalyst for biginelli reaction. J Mol Struct 1160:161

30. Pachamuthu MP, Shanthi K, Luque R, Ramanathan A (2013) SnTUD-1: a solid acid catalyst for three component coupling reactions at room temperature. Green Chem 15:2158

31. Pachamuthu MP, Rajalakshmi R, Maheswari R, Anand R (2014) Direct glycol assisted synthesis of amorphous mesoporous silicate with framework incorporated $\mathrm{CO}^{2+}$ characterization and catalytic application in ethylbenzene oxidation. RSC Adv 4:29909

32. Pachamuthu MP, Srinivasan VV, Maheswari R, Shanthi K, Ramanathan A (2013) Lewis acidic ZrTUD-1 as catalyst for tert-butylation of phenol. Appl Catal Gen 462:143

33. Mishra G, Behera GC, Singh SK, Parida KM (2012) Liquid phase esterification of acetic acid over $\mathrm{WO}_{3}$ promoted $\beta$-SiC in a solvent free system. Dalton Trans 41:14299

34. Bhuiyan TI, Arudra P, Akhtar MN, Aitani AM, Abudawoud RH, AlYami MA, Al- Khattaf SS (2013) Metathesis of 2-butene to propylene over W-mesoporous molecular sieves: a comparative study between tungsten containing MCM-41 and SBA-15. Appl Catal Gen 467:224

35. Suresh $R$, Kamalakkannan D, Ranganathan $K$, Arulkumaran $R$, Sundararajan R, Sakthinathan SP, Vijayakumar S, Sathiyamoorthi K, Mala V, Vanangamudi G, Thirumurthy K, Mayavel P, Thirunarayanan G (2013) Solvent-free synthesis, spectral correlations and antimicrobial activities of some aryl imines. Spectrochim Acta 101A:239-248

36. Suresh $R$, Sakthinathan SP, Kamalakkannan D, Ranganathan $K$, Sathiyamoorthi K, Mala V, Arulkumaran R, Vijayakumar S, Sundararajan $R$, Vanangamudi $G$, Subramanian $M$, Thirunarayanan $G$, Vanaja G, Kanagambal P (2015) Solvent-free synthesis of azomethines, spectral correlations and antimicrobial activities of some E-benzylidene-4-chlorobenzenamines. Bull Chem Soc Ethiop 29(2):275-290

37. Kumar A, Krishnakumar B, Sobral AGFN, Subash B, Swaminathan M, Sankaran KR (2016) An efficient, rapid and solvent-free synthesis of branched imines using sulphated anatase-titania as a novel solid acid catalyst. Indian J Chem 55B:1231-1238

Publisher's Note Springer Nature remains neutral with regard to jurisdictional claims in published maps and institutional affiliations. 